will inspire further benefactors to give it the means to go forward with the work of placing the higher branches of knowledge within the reach of "persons of the poorer classes".

\section{Portrait of Sir Flinders Petrie, F.R.S.}

ON Sir Flinders Petrie's retirement from the Edwards professorship of Egyptology in the University of London, many of his friends and admirers desired to commemorate his long tenure of that chair. It was decided that the memorial should take the form of a portrait of the great pioneer in the science of archæology, to be presented to University College, where he had worked for forty years. An appeal for subscriptions met with a generous response and, on Sir Flinders Petrie's visit to England in the summer, the portrait was painted by Mr. Philip de Laszlo. On November 23, Sir Henry Lyons made the presentation to the College on behalf of the subscribers, of whom a large number were present ; Sir John Rose Bradford accepted the gift on behalf of the College. The portrait is an exceptionally fine example of the artist's work and a striking likeness of Sir Flinders Petrie.

IN presenting the portrait to the College, Sir Henry Lyons referred to the debt to Sir Flinders Petrie of archæology in general and Egyptology in particular. He recalled that during the forty years Sir Flinders has been connected with the College, he has combined the duties of teaching with work in the field, at first and for long in Egypt and afterwards in Palestine. He has applied the method of exact measurement and scientific observation, which he employed in the investigation of the ancient monuments of Great Britain, to the study of the monuments of Giza, so that not only have his measurements of the pyramids been the first observations of exact value, but they have been fully confirmed by the measurements made much later under far more favourable conditions by the Survey of Egypt. From both Egypt and Palestine he has brought back a harvest of material objects and recorded observation, of which the prompt publication was his first eare. In the application of scientific methods to archæological investigation he has been a pioneer and his methods have been adopted and extended by those whom he himself had trained and by others. Here Sir Henry might well have referred to Sir Flinders' elaboration of the system of sequence dating which has remained the principal means of scientific chronological analysis in archæological investigation ever since he first formulated it, and is largely responsible for the great advances in recent archæological exploration in the near East to which Sir Henry went on to allude. All archæologists will cordially concur in the note on which he concluded, when he spoke of Sir Flinders as an inspiring teacher, who has brought home to a wider public "the interest and importance of Ancient Egypt in human history", and as one who well merits this record in the College in which he has worked.

\section{Dr. C. E. Guillaume}

THE degree of doctor honoris causa of the University of Paris was conferred on M. C. E. Guillaume, director of the Bureau international des Poids et Mesures at Sèvres, on November 10, in course of the annual meeting held at the reopening of the University, with M. Charlety, the rector, presiding. The inauguration address was read by the dean of the faculty of sciences, Prof. Maurain. M. Guillaume, a Swiss citizen, has been doing work in France for nearly fifty years at the Bureau international, first as assistant, and for twenty years as director. A fervent metrologist, M. Guillaume has fostered every improvement likely to increase the accuracy of the measurements. His painstaking investigations in thermometry and in the measurement of length made him look for possibilities of diminishing the effects of temperature. Hence followed a laborious research on special alloys, which led to the discovery of his famous 'invar', a nickel alloy of which the coefficient of expansion is practically negligible. But metrology did not monopolise M. Guillaume's thoughts. A good many people have enjoyed reading his "Initiation à la mécanique", a pleasant booklet reflecting the leading ideas in physics at the beginning of the twentieth century. Besides purely scientific work, M. Guillaume has done much to further the use of the metric system, as a means to ensure international collaboration. As the Director of the Bureau international, created in 1875 , M. Guillaume has had the satisfaction of seeing the system adopted even in oriental countries such as the U.S.S.R., Japan, Turkey, Persia, Afghanistan, Siam, Iraq and China. His report to the International Conference of Weights and Measures in 1933 dealt with the "Recent Progress of the Metric System" and raises the hope of the early and universal adoption of this system.

\section{Broadcast of the Royal Wedding Service}

THE broadcasting of the wedding service of H.R.H. The Duke of Kent and Princess Marina from Westminster Abbey on November 29 was described by the Times wireless correspondent as an unparalleled technical feat of the B.B.C. engineers. All who listened on this occasion will agree completely with this opinion; while those whom circumstances compelled to wait for the re-broadcast of the ceremony in the evening programme will have been equally impressed by the very high quality of the recording and reproducing technique. A brief description of the technical arrangements adopted for this occasion was given in World Radio of November 23, from which it is quite clear that the wireless listener was in a much better position, so far as hearing was concerned, than were probably most of those who attended the wedding service in the Abbey itself.

Fourteen microphone circuits were installed in suitable locations in and near the Abbey, and were connected to a control room installed in the crypt. 
The microphones used were of the moving coil type and, with one exception, they were carefully hidden. The engineer responsible for the arrangements sat in the crypt operating the controls for the various microphones required for the different portions of the ceremony, ranging from the running commentary outside the Abbey to the actual service at the altar steps. The various circuits were faded in and out so smoothly that the impression conveyed to the listener was that only one microphone was being used, and that it was being transferred from point to point as required. Four special telephone circuits were established between the control room and Broadcasting House, and from the latter centre the programme was distributed through all the home and Empire broadcasting stations. The developments of broadcasting and communications technique during recent years were utilised in the above manner to make this wedding ceremony an outstanding event in history ; for, as the Archbishop of Canterbury remarked in his address, never before has a marriage been attended by so vast a company of witnesses.

\section{An Experimental Railway Journey at High Speed}

ON November 30, the London and North Eastern Railway made an experimental run with a train from London to Leeds and back, to demonstrate what the possibilities were with steam as compared with oil. For the outward journey, the train was made up of locomotive No. 4472, a 'Flying Scotsman' engine, with a dynamometer car, a first-class corridor coach, a dining car and a brake van, while for the homeward journey two other corridor coaches were added, increasing the weight behind the engine from 145 tons to 205 tons. The train left King's Cross at 9.8 a.m. and arrived at Leeds at 11.39 a.m., the distance being 185.7 miles and the average speed being 73.4 miles per hour. The return journey was begun at 2.0 p.m. and ended at 4.37 p.m. During the return run, between Grantham and Peterborough, a maximum speed of 100 miles an hour was recorded, while during the climb from Tallington to Corby the speed was never less than 80 miles per hour. The experimental run was intended as a test of the steam locomotive burning coal on a service similar to that now run in foreign countries by trains with Dieselengined locomotives. The most notable of these trains at the present moment is the Flying Hamburger, which covers the distance between Berlin and Hamburg daily at an average speed of 77 miles an hour. The line over which the Flying Hamburger travels is level and without curves, while the line between King's Cross and Leeds has gradients up to 1 in 100 , and several speed restrictions. Such a passage as that made on November 30 , of course, could not be made without a certain amount of dislocation to other traffic and it was expensive ; but it showed that the potentialities of the steam locomotive for high-speed work have not been exhausted. It is noteworthy that the engine used is stated to have run some $\mathbf{4 4 , 0 0 0}$ miles since its last overhaul.

\section{Launching of Long-Range Aeroplanes}

Investigation into the possibilities of a new method of overcoming the difficulties of taking off with fuel sufficient for a long flight together with a reasonable amount of useful load, will shortly be carried out under the auspices of the Air Ministry and Imperial Airways by the use of a 'composite seaplane' now being built by Messrs. Short Brothers of Rochester. The machine is a flying boat, with sufficient initial climb to be able to take off the water easily with an exceptionally heavy load. The major portion of this load is a high-speed float seaplane, the design characteristics of which are those required for economical long-distance flight. It is carried practically on the wings of the flying boat, from which it can be released when sufficient speed and height are attained. The power of both of the machines is used for taking off. For this experiment a small single-engined seaplane will be used, which will probably not be seaworthy enough to weather rough water on the open seas if compelled to alight. It is, however, capable of flying to the Azores under normal conditions, and in the rarely favourable case of a continuous following wind, even to fly the whole of the direct crossing to America. The problem of securing exceptional range has hitherto been dealt with by refuelling in the air immediately after start. ing. The operating aircraft takes off with a small fuel load and is then filled from a 'tanker' machine, by means of a trailing hose picked up and connected while in flight. This system has been developed successfully by the R.A.F., but has never been used extensively for either military or commercial purposes.

\section{Airship Developments in the United States}

According to Science Service, of Washington, D.C., one of the older U.S. naval Zeppelin airships, the Los Angeles, has been reconditioned and made fully airworthy for a series of experiments upon mooring. It will be maintained in ordinary flying condition and moored out of doors, in the usual way, for at least a complete year. Experience thus gained will help to settle a number of questions upon which it is impossible to theorise. These include estimation of the velocity and extent of winds and gusts, the behaviour of the airship when under the effects of these and other meteorological conditions, the best handling of the ship to counteract the adverse effects of such, taking on supplies, fuel, etc., development of the ideal mooring system, and methods of docking into a hangar. Such information should be obtained with greater expedition and safety, using a trained experimental staff in this way, than endeavouring to gain similar experience during the normal using of the airship in service.

\section{Development of Cargo Vessels}

The seventh Thomas Lowe Gray lecture to the Institution of Mechanical Engineers was delivered on November 30 by Mr. L. St. L. Pendred, who took for the title of his lecture "A Survey of Ships and Engines". Although, in the first part of his lecture, 